\title{
Removal of Heavy Metals from Industrial Wastewater Using Rice Husks
}

\author{
I Nhapi ${ }^{1}, \mathrm{~N}_{\text {Banadda }}{ }^{2}$, , R Murenzi ${ }^{3}$, C.B Sekomo ${ }^{3}$ and U.G Wali ${ }^{3}$ \\ ${ }^{1}$ WREM Project, National University of Rwanda, P.O. Box 117 Butare, Rwanda \\ ${ }^{2}$ Department of Agricultural and Bio Systems Engineering, Makerere University, P.O. Box 7062, Kampala, Uganda \\ ${ }^{3}$ Department of Civil Engineering, University of Zimbabwe, Box MP169, Mt. Pleasant, Harare, Zimbabwe
}

\begin{abstract}
Heavy metals are widely used in textile industries and significant losses occur during the manufacture and processing of textiles, and these lost heavy metals are discharged in the effluent. Adsorption of heavy metals is a new technology for treatment of wastewater containing different types of selected heavy metals. In this study, adsorbents Carbonized Rice Husk (CRH) and Activated Rice Husk (ARH) made out of rice husks, available as agriculture waste, are investigated as viable materials for treatment of $\mathrm{Pb}, \mathrm{Cd}, \mathrm{Cu}$, and $\mathrm{Zn}$ containing industrial wastewater at controlled $\mathrm{pH}$. The results obtained from the batch experiments revealed a relative ability of the rice husk in removing some heavy metals at $\mathrm{pH}$ 7. One hand one, the CRH adsorption capacity decreases in the order of $\mathrm{Cu}>\mathrm{Pb}>\mathrm{Zn}>\mathrm{Cd}$ in batch adsorption whereas during Rapid Small Scale Column Tests the adsorption capacity decrease as follow $\mathrm{Cu}>\mathrm{Zn}>\mathrm{Pb}>\mathrm{Cd}$. On the other hand, ARH adsorption capacity performance is similar to CRH. However, during Rapid Small Scale Column Tests the adsorption capacity decreases in the order $\mathrm{Zn}>\mathrm{Cu}>\mathrm{Pb}>\mathrm{Cd}$. The kinetic removal in batch experiment shows that the net uptake of $\mathrm{Pb}, \mathrm{Cd}, \mathrm{Cu}, \mathrm{Zn}$ was $54.3 \%, 8.24 \%, 51.4 \%$ and $56.7 \%$, respectively whereas using $\mathrm{CRH}$, while it varied as $74.04 \%, 43.4 \%, 70.08 \%$ and $77.2 \%$ for the same dosages of ARH. Therefore, it is concluded that as regards to CRH, ARH demonstrated higher potential to remove relatively all selected heavy metals.
\end{abstract}

Keywords: Heavy metals, adsorbent, Carbonized Rice Husk, Activated Rice Husk, wastewater, adsorption isotherm.

\section{INTRODUCTION}

The international community is committed to achieving the Millennium Development Goals (MDGs) and in particular the target of halving by 2015 the proportion of the world's poor whose income is less than one dollar a day [1]. As the primary driver of economic growth and employment creation, the private sector has a central role in poverty reduction and the achievement of the MDGs. In Rwanda, 90\% of the population depends on agriculture, with the poorest depending for livelihoods on forests, fishing and wetlands and the ecosystem functions they provide [2]. About $30 \%$ of morbidity in Rwanda is due to environmental causes and $20 \%$ of child mortality is due to diarrhea, cholera and related diseases causes by polluted water and lack of sanitation [3].

The Government of Rwanda, in the face of growing evidence of the role of environment and natural resources in sustainable development, sought partnership to promote the integration of environment into national planning processes and economical development strategies such as industrialization. Industrial activities are major source of water pollution due to industrial chemicals which contain heavy metals, hazardous waste which can affect health and environment.

*Address correspondence to this author at the Department of Agricultural and Biosystems Engineering, Makerere University, P.O. Box 7062, Kampala, Uganda; Tel: +256 7740466 89; Fax: +25641453 16 41;

E-mail: banadda@agric.mak.ac.ug
Common cleaning methods for the removal of heavy metals comprise membrane separation, electrochemical precipitation, emulsion per traction, ion exchange, pre-concentration, fertilization and adsorption. These methods differ with respect to cost, complexity and efficiency [4].

Developing countries face numerous challenges that sometime restrict investments geared at preserving the environment. Therefore, there is a need to develop an efficient, rapid and cheaper procedure for the removal of heavy metals from the effluents. Among these technologies, adsorption is a user-friendly technique for the removal of heavy metal. This process seems to be most versatile and effective method for removal of heavy metal [5]. The adsorption process is being widely used by various researchers for the removal of heavy metals [6-11] from waste streams and activated carbon has been frequently used as an adsorbent. Despite its extensive use in the water and wastewater treatment industries, activated carbon remains an expensive material. In recent years, the need for safe and economical methods for the elimination of heavy metals from contaminated waters has necessitated research interest towards the production of low cost alternatives to commercially available activated carbon.

Like many developing countries, Rwanda faces environmental challenges of wastewater management particularly industrial wastewater. This issue seems to be a subject which has not yet received adequate attention during the evolution of industries. Indeed very little investment has been made in 


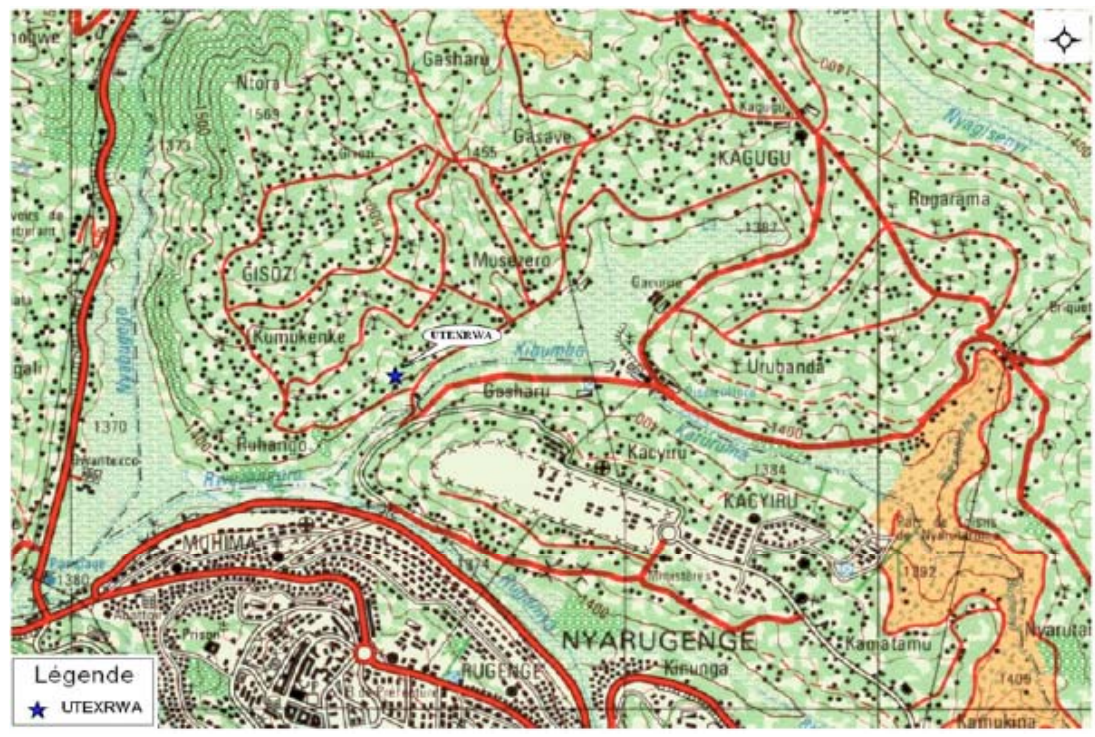

Fig. (1). Location of UTEXRWA in Kigali City, Rwanda.

the past on sewage treatment facilities, whilst water treatment and supply often received more priority than wastewater collection, treatment and reuse. Authors [12] reported that regarding industrial wastewater, few industries have appropriate individual sewage treatment systems and even where these exist, their functioning and maintenance are not satisfactory because of high cost of maintenance. The effluent quality for a number of industries does not comply with tolerance limits set by Rwanda Bureau of Standards [13]. Experiences from elsewhere [e.g., 14-17] show that low cost agroresidues have the capacity to purify wastewater containing heavy metals. The aim of this study is to investigate the applicability of adsorptive treatment using available agroresidue, carbonized and activated rice husk for the removal of selected heavy metals from industrial wastewater.

\section{MATERIALS AND METHODS}

\subsection{The Study Area}

One of the sources of heavy metals, the textile plant called UTEXRWA is located in Gacuriro valley, between Gisozi and Kacyiru sectors in Gasabo district, Kigali city (Rwanda). This plant produces tissues in polyester, cotton and in polyester/cotton. Raw materials used are polyester, cotton and dyes. Fig. (1) below shows the location of UTEXRWA in Kigali City, Rwanda. The red lines indicate the different local council communities in Kigali City.

\subsection{Effluent Treatment at UTEXRWA Plant}

The UTEXRWA has a wastewater treatment (see Fig. 2) plant composed of:

- A neutralization basin or raw influent tank of dimensions 8 by 8 by $2.5 \mathrm{~m}^{3}$ A flocculation tank of diameter $5 \mathrm{~m}$ by height $2.5 \mathrm{~m}$

- An aeration tank of dimensions 9 by 9 by $3 \mathrm{~m}^{3}$ with a surface aerator

- Clarification tank of diameter $5 \mathrm{~m}$ by height of $2.5 \mathrm{~m}$ with sludge recirculation pump

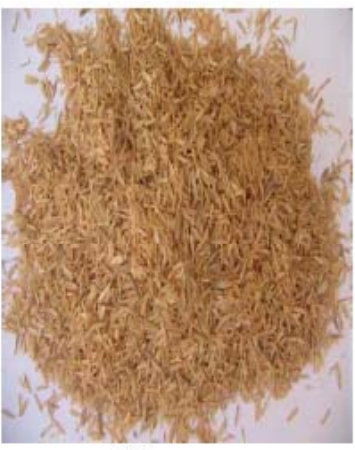

(a)

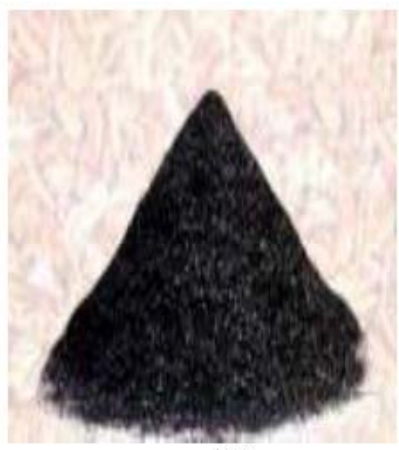

(b)
Fig. (2). Rice husks of varying particle sizes of 45, 75, 106, 180 and $250 \mu \mathrm{m}$ (a) before treatment and (b) after treatment.

- The design wastewater parameters are:

- Influent: discharge rate: $20 \mathrm{~m}^{3} / \mathrm{h} \quad\left(\mathrm{BOD}_{5}: 135 \mathrm{mg} / \mathrm{l}\right.$; COD: 450mg/1 ; MES: 55-60mg/1 ; pH: 9.5)

- Effluent discharge rate: $\mathrm{BOD}_{5}$ : $<20 \mathrm{mg} / 1 ; \mathrm{COD}$ : $<100 \mathrm{mg} / 1$; MES: <30mg/1; pH: 7-9.

The key point is that this is a conventional WWTP and is not designed to remove heavy metals. The effluent from UTEXRWA wastewater plant is discharged into rivers called Rwenzangoro and Rwanzekuma, which in turn discharge into Nyabugogo River which also discharges into Nyabarongo River.

\subsection{Sampling and Preparation of Sorbents}

\subsubsection{Sampling of Adsorbents}

The biomass sample used in this study for adsorption of heavy metals from industrial wastewater was rice husk. The husks were provided by Karubanda rice mill located in Huye district and treated in the laboratory in order to get material desired for carbonization and activation. Husk is a layer of cellulose protecting rice grain. The Fig. (2) shows some samples of rice husks before treatment. 


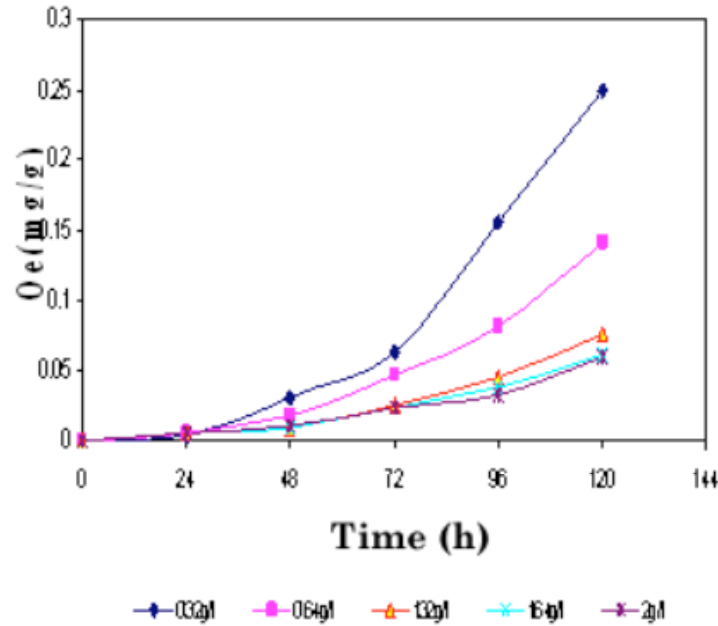

Fig. (3). $\mathrm{Pb}$ (II) per unit time a function of $\mathrm{CRH}$ adsorbed.

\subsubsection{Preparation of Sorbents}

Rice husk was washed several times with de-ionized water to remove all dirt in its original particle size followed by filtration and were dried at $100^{\circ} \mathrm{C}$. The cleaned and dried rice husk was oven dried at $500^{\circ} \mathrm{C}$ for 3 hours without any other further treatment to form what is called Carbonized Rice Husks (CRH).

Typical chemical composition of the mineral ash is: $96.34 \% \mathrm{SiO}_{2}, 2.31 \% \mathrm{~K}_{2} \mathrm{O}, 45 \% \mathrm{MgO}, 0.41 \% \mathrm{CaO}$ and $0.2 \%$ $\mathrm{Fe}_{2} \mathrm{O}_{3}$. Chemical and physical properties of rice husk ash heated at $400^{\circ} \mathrm{C}$ are: $1.88 \%$ carbon, $79.27 \%$ silicon dioxide [18]. Activated carbon is an amorphous form of carbon, which is especially treated to produce a very large surface ranging from 300 to $2000 \mathrm{~m}^{2} / \mathrm{g}$ [19]. The purpose of this work was to improve textural parameters of carbons obtained from rice husk $100 \mathrm{~g}$ of carbonized rice husks were soaked in $0.6 \mathrm{M}$ of citric acid for 2 hours at $20^{\circ} \mathrm{C}$. Acid husk slurry is dried overnight at $50^{\circ} \mathrm{C}$ and the dried husks are heated to $120^{\circ} \mathrm{C}$ under aerobic conditions. The reacted product was washed repeatedly with distilled water $(200 \mathrm{ml} / \mathrm{g})$. Finally the cleaned rice husk was oven dried overnight at $100^{\circ} \mathrm{C}$. The test solutions were prepared by diluting of stock solution containing $1000 \mathrm{mg} / \mathrm{l}$ of $\mathrm{Cu}$ (II), $\mathrm{Cd}(\mathrm{II}), \mathrm{Pb}(\mathrm{II}), \mathrm{Zn}(\mathrm{II})$ to the desired concentrations. Before mixing the adsorbent, the $\mathrm{pH}$ of each test solution was adjusted to the required value with diluted with $\mathrm{H}_{2} \mathrm{SO}_{4}$ and concentrated with $\mathrm{NaOH}$ solution. All $\mathrm{pH}$ measurements were carried out with a $\mathrm{pH}$ meter model Hanna 211. Solutions of $\mathrm{Zn}$ (NO3). $6 \mathrm{H}_{2} \mathrm{O}$, $\mathrm{Cd}\left(\mathrm{NO}_{3}\right) \cdot 4 \mathrm{H}_{2} \mathrm{O}, \mathrm{Cu}\left(\mathrm{NO}_{3}\right)_{2} .3 \mathrm{H}_{2} \mathrm{O}, \mathrm{Pb}\left(\mathrm{NO}_{3}\right)_{2}$ were used in adjusting concentrations of heavy metals contained in wastewater and $\mathrm{HNO}_{3}(68 \%)$ was used in the acidification of wastewater samples.

\subsection{Adsorption Studies}

Sorption studies were conducted in a routine manner by the batch technique using synthetic wastewater and Column test using real wastewater from UTEXRWA.

\subsubsection{Batch Experiments and Adsorption Isotherms}

A series of batch experiments were carried out to determine the adsorption isotherms of selected heavy metals on the adsorbents. Each heavy metals solution of $\mathrm{Pb}, \mathrm{Cd}, \mathrm{Cu}, \mathrm{Zn}$ was placed in $500 \mathrm{ml}$ beakers at $\mathrm{pH} 7 \pm 0.2$ and a known amount of rice husk were added to each beaker. The mass (g) of carbonized/activated rice husks were $0.16,0.32,0.66$, 0.82 and 1.0. The flasks were shaken at a constant rate of $250 \mathrm{rpm}$ to ensure that equilibrium was reached. It was assumed that the applied shaking speed allows all the surface area to come in contact with heavy metals ions over the course of the experiments The study were performed at a constant temperature of $25^{\circ} \mathrm{C}$ to be representative of environmentally relevant condition. All the experiments were carried out in duplicates and the average value were used for further calculation. To avoid the fluctuation of $\mathrm{pH}$ due to the exchange of gases during the experiment the bottles were capped and kept closed as depicted in Fig. (3).

The amount of metal adsorbed per unit mass is calculated as

$\mathrm{Qe}=(\mathrm{Co}-\mathrm{Ce}) \mathrm{V} / \mathrm{m}$

where $\mathrm{Co}$ and $\mathrm{Ce}$ are the initial and equilibrium concentration $(\mathrm{mg} / \mathrm{l}), \mathrm{m}$ is the mass of the adsorbent $(\mathrm{g})$ and $\mathrm{V}$ is the volume of the solution $\left(\mathrm{m}^{3}\right)$.

\subsubsection{Column Test}

This experiment is useful in understanding and predicting the behavior of the process. 1.62g of either CRH) or (ARH) was added to the treatment glass columns $(150 \times 20 \mathrm{~mm})$. The adsorption experiments were carried out in columns that were equipped with a stopper for controlling the column flow rate. Afterwards, the $\mathrm{pH}$ has been adjusted to 7 with $\mathrm{H}_{2} \mathrm{SO}_{4}$ and $\mathrm{NaOH}$ solutions. The sample solution was passed through the adsorption column at a flow rate of $10 \mathrm{ml} / \mathrm{min}$ by gravitation. A small mattress foam was inserted into the bottom of the column to prevent the loss of rice husk. The flow rate was kept constant by controlling the stopper value. The removal experiment was performed at ambient temperature. All the experiments were carried out in duplicates. Inlet of the column was connected to the 25 liter feed bucket with the silicon tubing. The concentration of residual individual heavy metal in the sorption medium was determined with AAS after the preparation of samples according to the standard methods [2]. To adjust concentration of heavy metals in real wastewater used in column test, a set of measurement concentration of the sample taken from UTEXRWA was carried out to the amount of heavy metals contained in wastewater.

\subsection{Sampling and Solution Stability}

In batch experiment, the samples were taken at regular time intervals of 24 hours to determine the rate of adsorption and equilibrium conditions (adsorbent-heavy metals solution). For the first week, samples were taken after every 24 hours and then the interval of 96 hours was respected during 13 days for batch experiments. For column test, an interval of $1 \mathrm{~h}$ during 2 sampling were respected until the equilibrium. 3 or 4 drops of nitric acid $68 \%$ were added to every sample taken for acidification. The stability of solution of heavy metals, namely $\mathrm{Pb}, \mathrm{Cd}, \mathrm{CU}$ and $\mathrm{Zn}$ was investigated. Synthetic water was used in adsorption experiments in Polypropylene (PP) bottles. PP bottles were put on the shaker and 


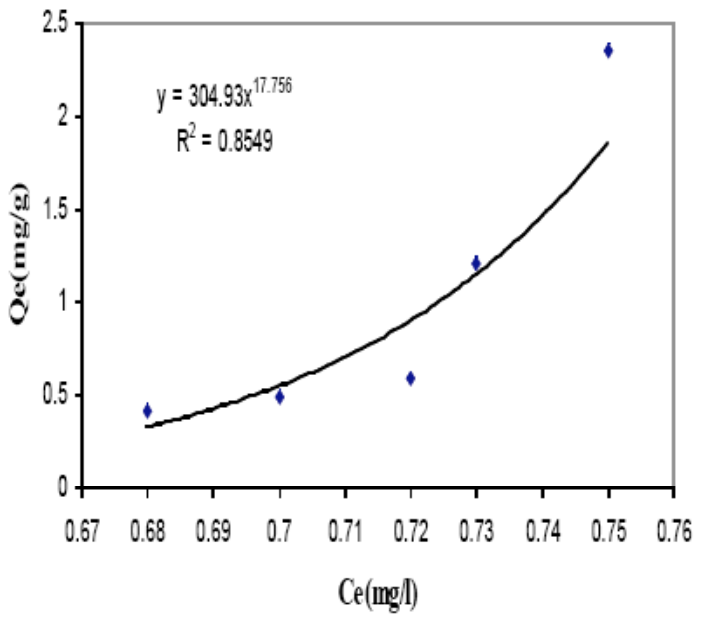

Fig. (4). Adsorption isotherm for $\mathrm{Pb}$ with $\mathrm{CRH}$.

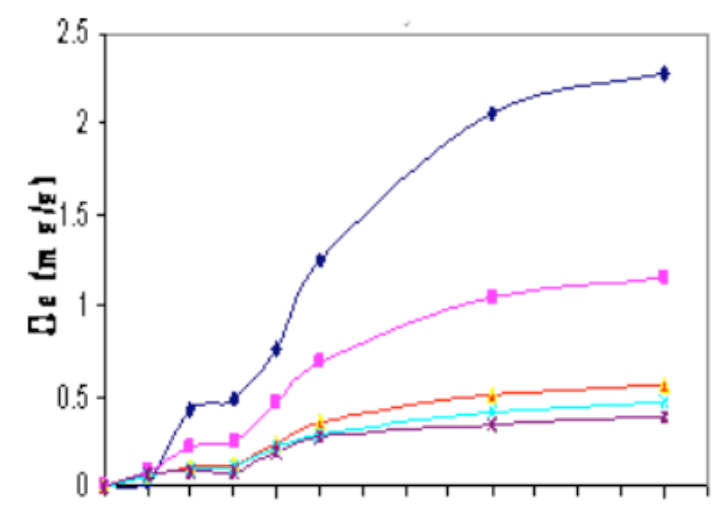

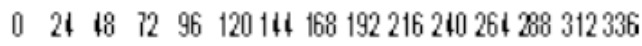

\section{Time (h)}

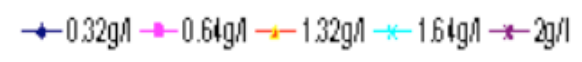

Fig. (5). Cd per unit time a function of CRH adsorbed.

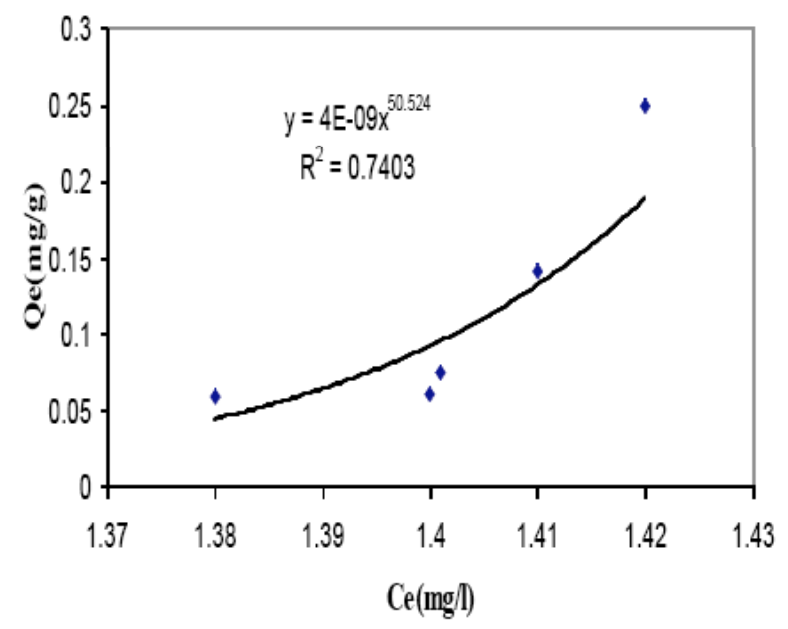

Fig. (6). Freundlich isotherm for Cd with CRH.

shaken at speed of $250 \mathrm{rpm}$. Sampling was done at 24 hours regular time intervals and samples were analyzed for them. No significant change in concentration was observed in the blank bottles.

\section{RESULTS AND DISCUSSION}

\subsection{Adsorption on CRH}

A series of batch adsorption experiment were conducted to establish the isotherm for $\mathrm{Pb}, \mathrm{Cd}, \mathrm{Cu}$ and $\mathrm{Zn}$ adsorption on CRH. This section presents the result of batch adsorption isotherm of different metal with CRH

\subsubsection{Adsorption of Pb on CRH}

Fig. (3) shows the amount of $\mathrm{Pb}(\mathrm{II})$ adsorbed per unit mass of CRH as a function of time. It was observed that adsorption capacity reached equilibrium after $120 \mathrm{hrs}$ beyond which there was only negligible change in the residual $\mathrm{Pb}$ (II) concentration. The uptake capacity of $\mathrm{Pb}$ (II) increases with increase in the amount of adsorbents. For the initial concentration of $1.5 \mathrm{mg} / \mathrm{l}$ the net uptake of $\mathrm{Pb}$ (II) varied from $50.1 \%$ to $54.7 \%$ for an adsorbents dose of 0.32 and $2 \mathrm{~g} / 1$.

The amount of $\mathrm{Pb}$ (II) adsorbed per unit mass of $\mathrm{CRH}$ has been plotted against the equilibrium $\mathrm{Pb}$ (II) concentrations in solution (Fig. 4). The correlation coefficient of $R^{2}=0.85$, it was concluded that the data fitted the Freundlich isotherm model. The Freundlich isotherms constant (K) was found to be 304 and $1 / \mathrm{n}$ value is 17 which shows the adsorption is (high value of $1 / \mathrm{n}$ ) not favorable to adsorption ( $\mathrm{K}$ and $\mathrm{n}$ are constants for a given adsorbate and adsorbent at a particular temperature. The steep slope shows that the adsorption took place in the first 120 hours and then after adsorbent was exhausted. The amount of $\mathrm{Pb}$ adsorbed was increasing while the equilibrium concentration was not changing.

\subsubsection{Adsorption of Cd on $\mathrm{CRH}$}

Fig. (5) shows the amount of $\mathrm{Cd}$ adsorbed per unit weight of $\mathrm{CRH}$ as a function of $\mathrm{CRH}$ dosage and adsorption time. At the end of the experiment, a net adsorption of $\mathrm{Cd}$ was found to vary from $5.3 \%$ to $8 \%$ with an increasing dose of $\mathrm{CRH}$ from $0.32 \mathrm{~g} / \mathrm{l}$ to $2 \mathrm{~g} / \mathrm{l}$. This bad removal could be attributed to adsorption which depends in this case to chemical interaction instead of electrostatic attraction.

Fig. (6) shows the isotherm of $\mathrm{Cd}$ adsorption on $\mathrm{CRH}$. The correlation of $\mathrm{R}^{2}=0.74$ indicates that results obtained fits well Freundlich isotherm model. The Freundlich isotherm constants $\mathrm{K}$ and $1 / \mathrm{n}$ value were found to be 11.327 and -14.096 indicates that adsorption is not favorable and that desorption can take place easily since the $\mathrm{Cd}$ is not strongly bonded to CRH.

\subsubsection{Adsorption of $\mathrm{Cu}$ on $\mathrm{CRH}$}

Fig. (7) shows the amount of copper adsorbed per unit weight of $\mathrm{CRH}$ as a function of $\mathrm{CRH}$ dosage and adsorption time. The experiment was performed continuously for 216 hrs until the concentration of copper in solution did not significantly change. Because the decrease in the dissolved metal concentration is due to both precipitation and adsorption, the precipitation as found in the blank was not significant. At the end of the experiment, a net adsorption of copper was found to vary from $48.6 \%$ to $51.4 \%$ with an increasing dose of CRH from. 0.32 to $2 \mathrm{~g} / \mathrm{l}$. 


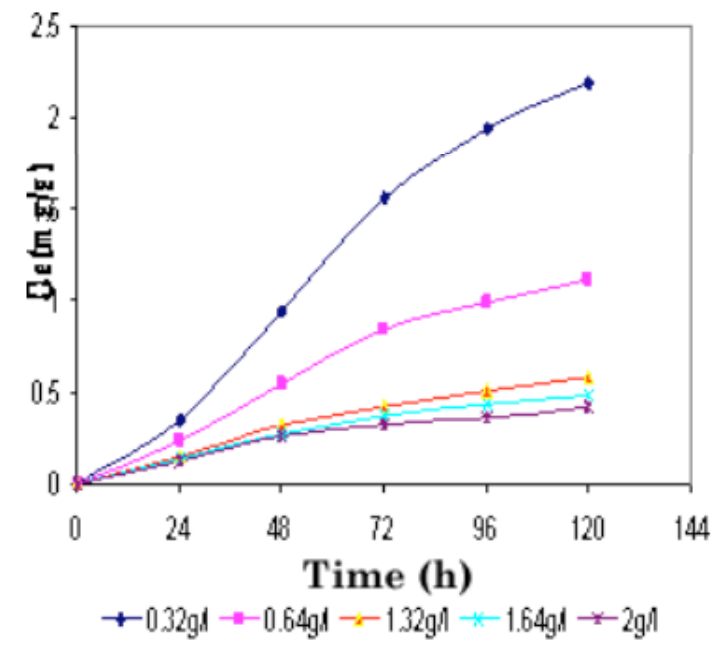

Fig. (7). $\mathrm{Cu}$ per unit time a function of $\mathrm{CRH}$ adsorbed.

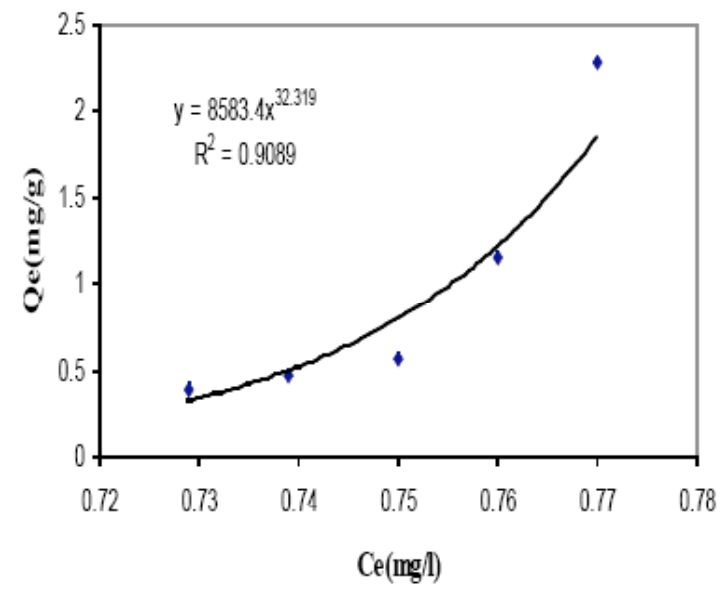

Fig. (8), Freundlich isotherm for $\mathrm{Cu}$ with $\mathrm{CRH}$.

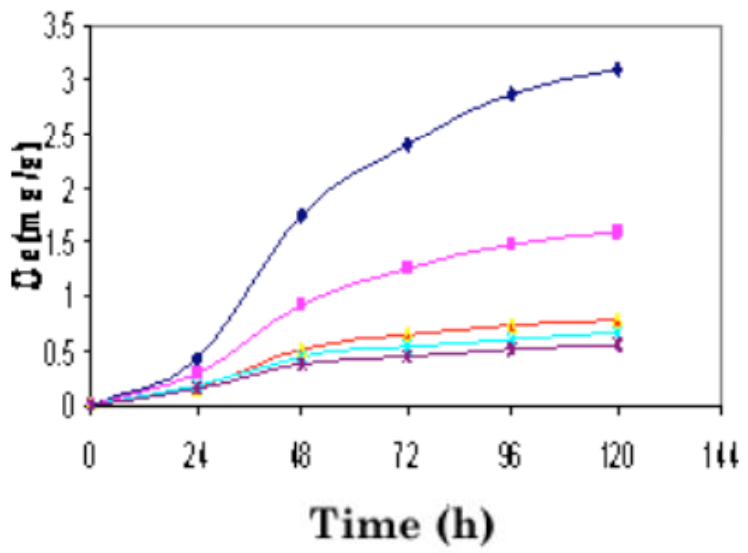

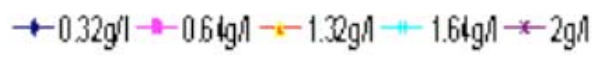

Fig. (9). Zn per unit time a function of $\mathrm{CRH}$ adsorbed.

For the determination of adsorption isotherm, amount of copper adsorbed per unit mass of CRH was plotted against the equilibrium $\mathrm{Cu}$ concentration. Experimental data fitted reasonably well in the Freundlich isotherm model $\left(\mathrm{R}^{2}=\right.$ $0.91)$. Isotherm constant was high $(\mathrm{K}=8583$ of $\mathrm{CRH})$ indicating high adsorption capacity for $\mathrm{Cu}$. The $1 / \mathrm{n}$ value ob-

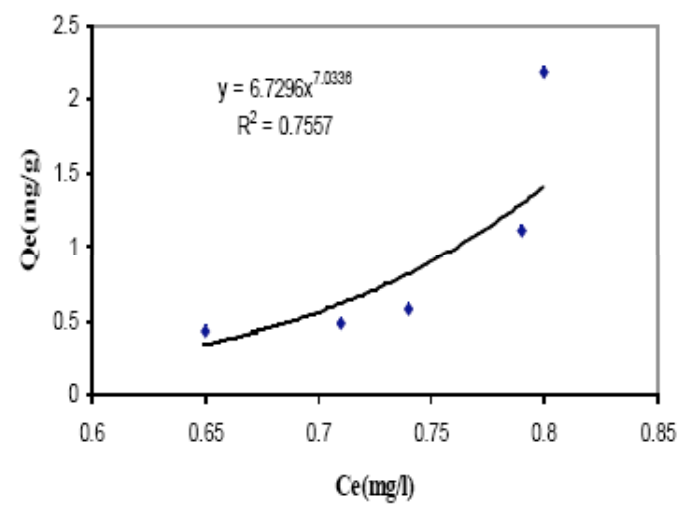

Fig. (10). Freundlich isotherm for $\mathrm{Zn}$ with $\mathrm{CRH}$.

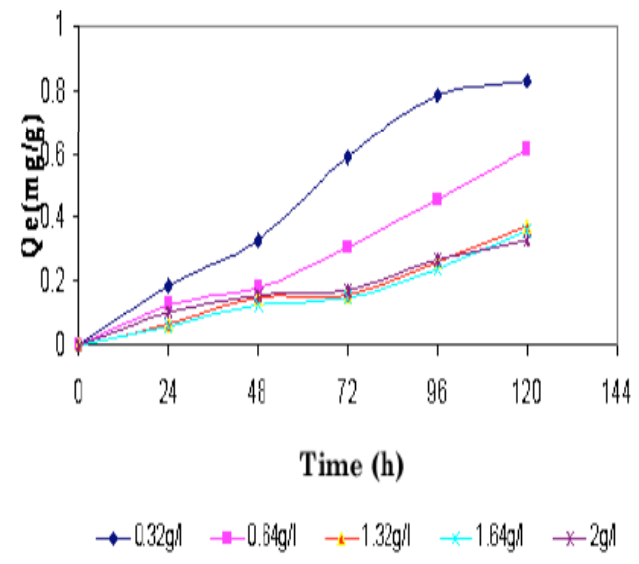

Fig. (11). $\mathrm{Pb}$ (II) per unit time a function of ARH adsorbed.

tained was relatively high (Fig. 8) which shows low adsorption.

\subsubsection{Adsorption of $\mathrm{Zn}$ on $\mathrm{CRH}$}

Fig. (9) shows the amount of copper adsorbed per unit weight of CRH as a function of CRH dosage and adsorption time. At the end of the experiment, a net adsorption of copper was found to vary from $46.6 \%$ to $56.6 \%$ with an increasing dose of CRH from. 0.32 to $2 \mathrm{~g} / \mathrm{l}$.

For the determination of adsorption isotherm, amount of Zinc adsorbed per unit mass of CRH was plotted against the equilibrium $\mathrm{Zn}$ concentration. The co-relation coefficient $\left(\mathrm{R}^{2}=0.76\right)$ suggests that data fits the Freundlich isotherm model. The adsorption capacity constant $\mathrm{K}$ was 6.7 whereas the adsorption intensity value was found to be 7.0 (Fig. 10). This shows high adsorption capacity of CRH for $\mathrm{Zn}$ but low adsorption because of high value of $1 / \mathrm{n}$.

\subsection{Adsorption on ARH}

A series of batch adsorption experiment were conducted with $\mathrm{ARH}$ to establish isotherms for $\mathrm{Pb}, \mathrm{Cd}, \mathrm{Cu}$ and $\mathrm{Zn}$. In what follows the adsorption isotherm of these metals and kinetic of removal are presented.

\subsubsection{Adsorption of $P b$ on $A R H$}

Fig. (11) shows the amount of $\mathrm{Pb}$ (II) adsorbed per unit mass of ARH as a function of time. The other bottles filled with same model water with different amount of ARH dosed. 


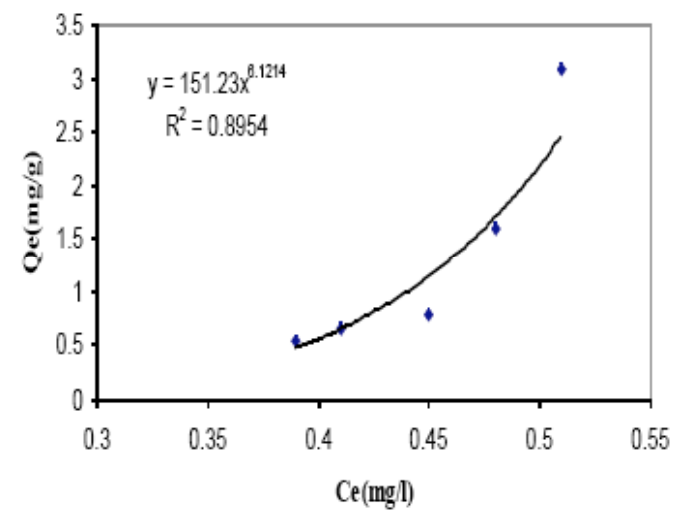

Fig. (12). Freundlich isotherm for $\mathrm{Pb}$ with $\mathrm{ARH}$.

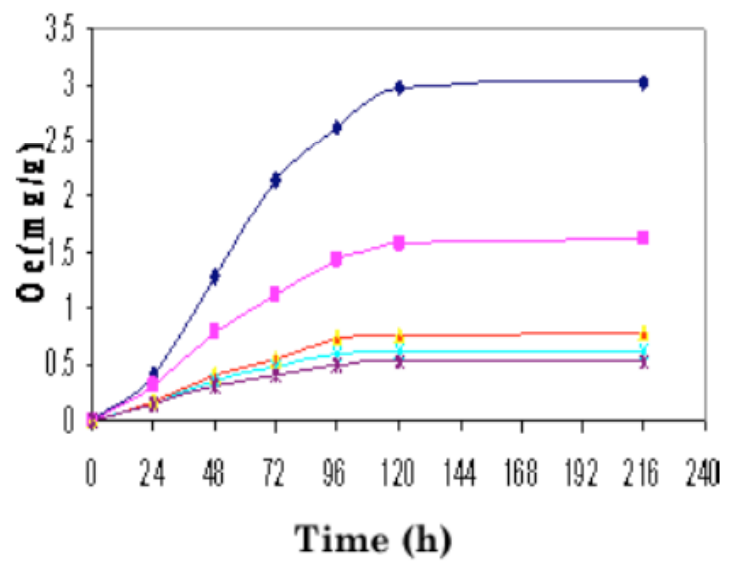

$$
\leftarrow 0.32 \mathrm{gl} \rightarrow-0.64 \mathrm{gi}-\mathrm{g}-1.32 \mathrm{gl}+1.64 \mathrm{gi}+2 \mathrm{gl}
$$

Fig. (13). Cd per unit time a function of ARH adsorbed.

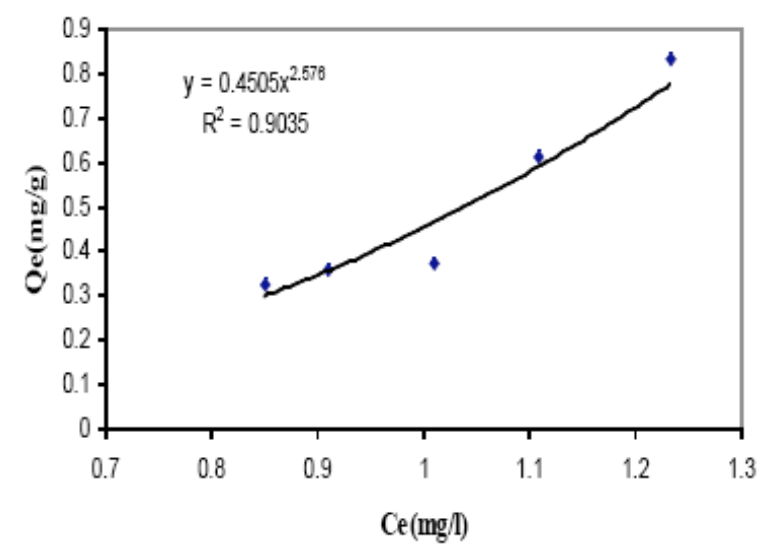

Fig. (14). Freundlich isotherm for Cd with ARH.

After 120 hours of equilibrium time $\mathrm{Pb}$ (II) uptake by $\mathrm{ARH}$ varied from $66 \%$ to $74 \%$ with ARH dose of $0.32-2 \mathrm{~g} / 1$.

The amount of $\mathrm{Pb}(\mathrm{II})$ adsorbed per unit mass ARH has been plotted against the equilibrium $\mathrm{Pb}$ (II) concentrations in the solution. Data fitted Freundlich isotherm models $\left(\mathrm{R}^{2}=0.90\right)$. The Freundlich isotherm constants $\mathrm{K}(\mathrm{mg} / \mathrm{g})$ and $1 / \mathrm{n}$ value were found to be 151.23 and 6.12 , respectively. This indicates that adsorption was better than what was observed with CRH (Fig. 5). Fig. (12) shows the Freundlich isotherm of $\mathrm{Pb}$ (II) removal with $\mathrm{ARH}$. The slope of the iso-

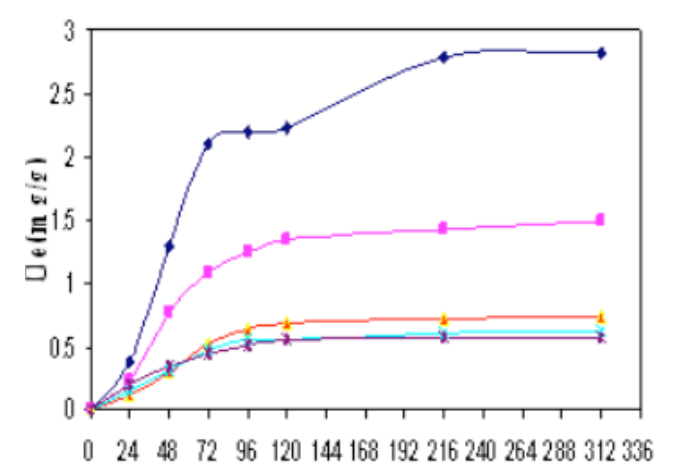

Time (h)

$$
\rightarrow 032 g^{\prime}\left|-0.6 \lg n-i .32 g^{\prime}\right|-1.6 i g\left|+2 g^{\prime}\right|
$$

Fig. (15). $\mathrm{Cu}$ per unit time a function of ARH adsorbed.

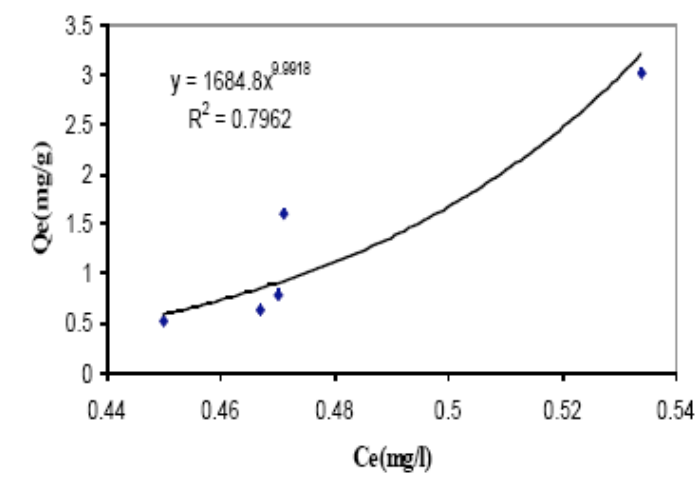

Fig. (16). Freundlich isotherm for $\mathrm{Cu}$ with $\mathrm{ARH}$.

therm line indicates that $\mathrm{ARH}$ adsorption capacity of $\mathrm{Pb}$ (II) increases significantly with a slight increase in equilibrium concentration.

\subsubsection{Adsorption of Cd on ARH}

Fig. (13) amount of cadmium adsorbed per unit weight of ARH. At the equilibrium cadmium uptake by ARH varied from $17.7 \%$ to $43.3 \%$ for ARH dosage of 0.32 and $2.0 \mathrm{~g} / 1$ respectively. It was clearly observed that ARH showed good performance to remove $\mathrm{Cd}$ compared to the performance of CRH (Fig. 8).

Fig. (14) shows the Freundlich isotherm for cadmium adsorption on ARH. The Freundlich isotherm constants $\mathrm{K}$ and $1 / \mathrm{n}$ were found to be 0.4 and 2.87 , respectively. The adsorption was favorable and cadmium compared to the results obtained with CRH (Fig. 8). The highly steep slope of the isotherm line indicates that amount of cadmium adsorbed changed significantly without the change of equilibrium concentration.

\subsubsection{Adsorption of Cu on ARH}

Fig. (15) shows the amount of $\mathrm{Cu}(\mathrm{II})$ adsorbed per unit mass of ARH. The other bottles filled with same model water with different amount of ARH dosed. After 120hours of equilibrium time $\mathrm{Cu}(\mathrm{II})$ uptake by $\mathrm{ARH}$ varied from 63.3 to $68.8 \%$ with ARH dose of $0.32-2 \mathrm{~g} / 1$.

Fig. (16) shows the Freundlich isotherm for $\mathrm{Cu}$ adsorption on ARH. Freundlich isotherm constants $\mathrm{K}$ and $1 / \mathrm{n}$ were 


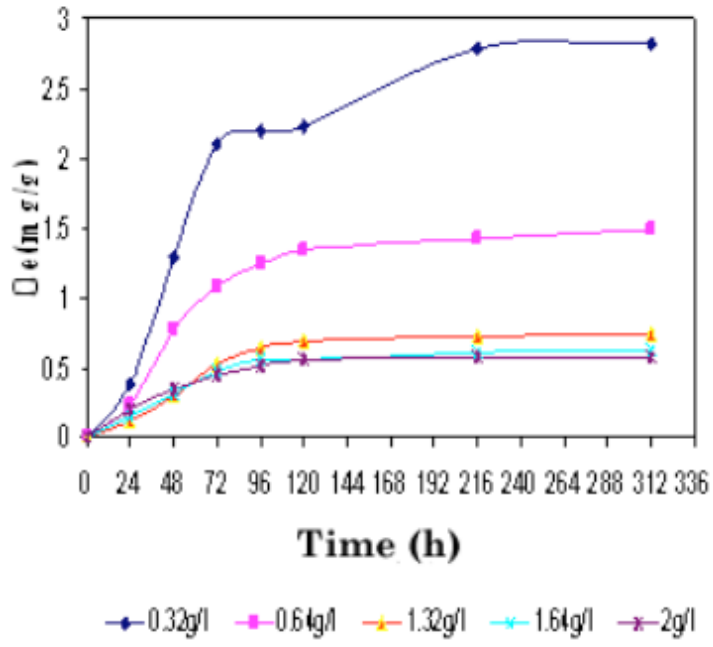

Fig. (17). Zn per unit time a function of ARH adsorbed.

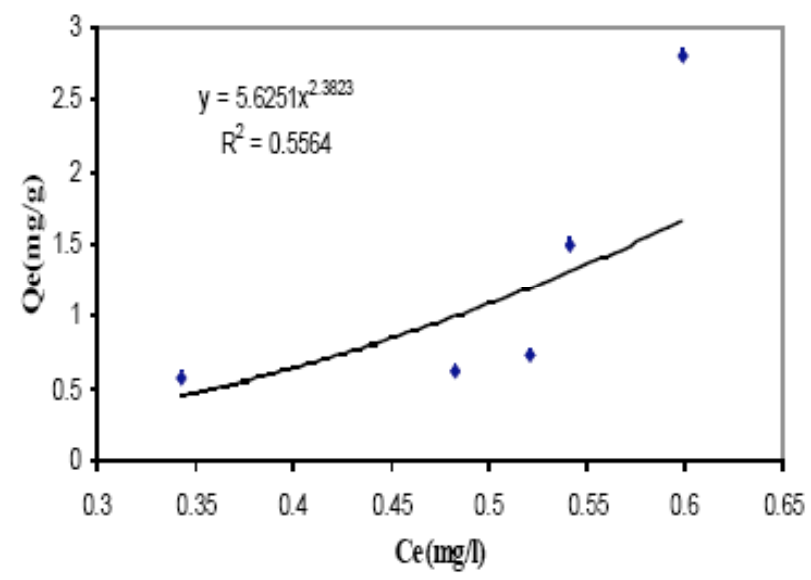

Fig. (18). Freundlich isotherm for $\mathrm{Zn}$ with $\mathrm{ARH}$.

found to be 1684 and 9.99 respectively indicating that adsorption capacity is very high but adsorption intensity which shows the adsorption is (high value of $1 / \mathrm{n}$ ) not favorable to adsorption on ARH. The highly steep slope of the isotherm line indicates that amount of Copper adsorbed is changing significantly without the change of equilibrium concentration.

\subsubsection{Adsorption of $\mathrm{Zn}$ on $\mathrm{ARH}$}

Fig. (17) shows the amount of $\mathrm{Zn}$ adsorbed per unit weight of ARH. The percentage of $\mathrm{Zn}$ removal increases with the dose of adsorbents but the amount of $\mathrm{Zn}$ adsorbed per unit weight of adsorbents increases with the doses of adsorbents.

For the determination of the adsorption isotherm, amount of $\mathrm{Zn}$ (II) adsorbed per unit weight of ARH is plotted against the equilibrium concentration of $\mathrm{Zn}$ (II). Experimental data does not fit the Freundlich isotherm model at all $\left(\mathrm{R}^{2}=0.56\right)$ as shown in Fig. (18). The Freundlich isotherm constants $\mathrm{K}$ $(\mathrm{mg} / \mathrm{g})$ and $1 / \mathrm{n}$ were found to be 5.6 and 2.38 which shows that the isotherm is favorable and $\mathrm{Zn}$ is bonded to the ARH. The slope of the isotherm line indicates that adsorption capacity is highly dependent on the equilibrium concentration. The higher the equilibrium concentration is the higher will

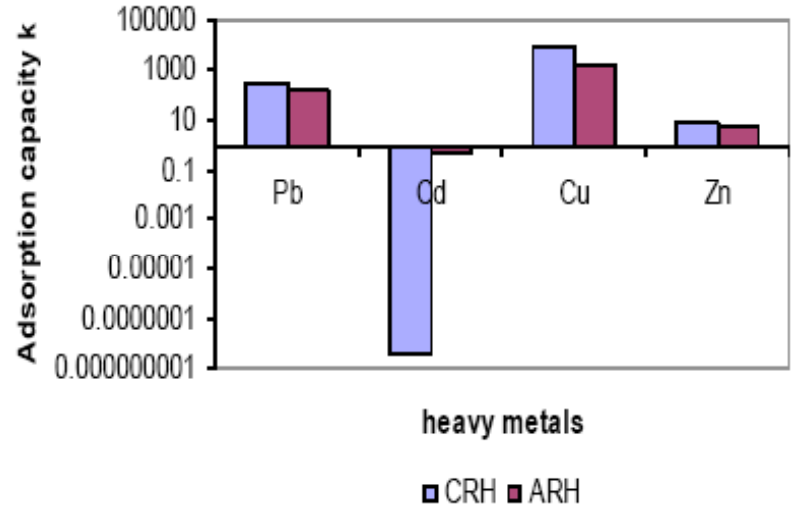

Fig. (19). Comparison of adsoprtion capacity of different heavy metals.

Table 1. Freundlich Isotherm Parameters with CRH and ARH

\begin{tabular}{|c|c|c|c|}
\hline Metals & Freundlich isotherm parameters & CRH & ARH \\
\hline \hline \multirow{3}{*}{$\mathrm{Pb}$} & Regression coefficient $\mathrm{R}^{2}$ & 0.855 & 0.895 \\
\cline { 2 - 4 } & K value & 304.93 & 151.23 \\
\cline { 2 - 4 } & $1 / \mathrm{n}$ value & 17.756 & 6.121 \\
\hline \multirow{2}{*}{$\mathrm{Cd}$} & Regression coefficient $\mathrm{R}^{2}$ & 0.7 & 0.90 \\
\cline { 2 - 4 } & K value & $4 \mathrm{E}-09$ & 0.45 \\
\cline { 2 - 4 } & $1 / \mathrm{n}$ value & 50.52 & 2.5 \\
\hline \multirow{3}{*}{$\mathrm{Cu}$} & Regression coefficient $\mathrm{R}^{2}$ & 0.909 & 0.796 \\
\cline { 2 - 4 } & K value & 8583.4 & 1684.8 \\
\cline { 2 - 4 } & $1 / \mathrm{n}$ value & 32.319 & 9.99 \\
\hline \multirow{2}{*}{$\mathrm{Zn}$} & Regression coefficient $\mathrm{R}^{2}$ & 0.75 & 0.5564 \\
\cline { 2 - 4 } & K value & 6.72 & 5.625 \\
\cline { 2 - 4 } & $1 / \mathrm{n}$ value & 7.0 & 2.38 \\
\cline { 2 - 4 } & & & \\
\hline
\end{tabular}

the adsorption capacity be. The $\mathrm{Zn}$ (II) adsorbed on CRH was 3 times higher than that adsorbed on ARH.

\subsection{Comparison of CRH and ARH in Batch Adsorption Experiment}

A comparison of Freundlich isotherm parameters for heavy metals was performed with CRH and ARH. Table 1 presents the summary of the Freundlich isotherm parameters.

Fig. (19) compares the net adsorption capacity of CRH and ARH expressed as Freundlich adsorption capacity (K). It was found that metal uptake by CRH decreases in the order of $\mathrm{Cu}>\mathrm{Pb}>\mathrm{Zn}>\mathrm{Cd}$. Similarly metal adsorption by ARH decreases in the order of $\mathrm{Cu}>\mathrm{Pb}>\mathrm{Zn}>\mathrm{Cd}$. Adsorption capacity of CRH used for $\mathrm{Cd}$ was found to be negligible. This is probably due to the surface charge of $\mathrm{CRH}$ at $\mathrm{pH}$ 7.0. The removal efficiencies of studied heavy metals increased gradually with increasing amount of rice husk. This implies that the adsorption capacity of rice husk depends on the surface activity, that is, the specific surface area available for metal-surface interactions that is accessible to the investigated metals. Hence, increasing the amount of rice husk will increase removal capacity of $\mathrm{Pb}, \mathrm{Cd}, \mathrm{Cu}$ and $\mathrm{Zn}$. 
Table 2. Physical Design Parameters of RSSCT with CRH and Corresponding Design Parameters for Large Scale Column

\begin{tabular}{|c|c|c|c|}
\hline Design Parameter (CRH) & Unit & RSSCT & $\begin{array}{c}\text { Large } \\
\text { Column }\end{array}$ \\
\hline \hline Column Inner Diameter & $\mathrm{cm}$ & 2.00 & 8.30 \\
\hline Column Inner Radius & $\mathrm{cm}$ & 1.00 & 4.15 \\
\hline $\begin{array}{c}\text { Column Inner Cross } \\
\text { Sectional Area }\end{array}$ & $\mathrm{cm} 2$ & 3.14 & 54.11 \\
\hline Loading Rate & $\mathrm{cm} / \mathrm{min}$ & 2.77 & 0.67 \\
\hline EBCT & $\mathrm{min}$ & 0.58 & 10.00 \\
\hline Flow Rate & $\mathrm{cm} 3 / \mathrm{min}$ & 10.00 & 36.09 \\
\hline Adsorbent Bulk Density & $\mathrm{g} / \mathrm{cm} 3$ & 0.32 & 0.32 \\
\hline Adsorbent Height & $\mathrm{cm}$ & 1.61 & 6.67 \\
\hline $\begin{array}{c}\text { Adsorbent Volume/Bed } \\
\text { Volume }\end{array}$ & $\mathrm{cm} 3$ & 5.05 & 360.89 \\
\hline Adsorbent Weight & $\mathrm{g}$ & 1.62 & 115.48 \\
\hline $\begin{array}{c}\text { Number of Bed Volume Per } \\
\text { Day }\end{array}$ & $\begin{array}{c}\text { Bed } \\
\text { Volume/Day }\end{array}$ & 2851.90 & 144.00 \\
\hline
\end{tabular}

RSSCT with Pb

RSSCT with CRH as adsorbents were conducted for $30 \mathrm{hrs}$ at which $95 \%$ breakthrough was reached (Figure 20). At $95 \%$ breakthrough $2.82 \mathrm{mg}$ of $\mathrm{Pb}$ (II) were adsorbed per $\mathrm{g}$ of CRH was adsorbed and 5443 bed volumes were treated.

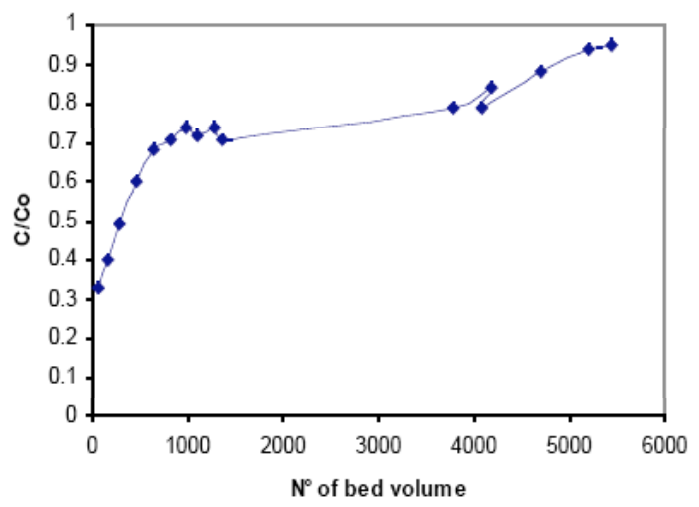

Fig. (20). Breakthrough profile for $\mathrm{Pb}$ with $\mathrm{CRH}$ as adsorbents.

\subsection{Rapid Small Scale Column Test}

As an additional measure to predict the performance of $\mathrm{CRH}$ and ARH in continuous flow system, Rapid Small Scale Column Tests (RSSCT) was performed. The main goal of RSSCT was to simulate the real condition for the use of these two adsorbents namely $\mathrm{CRH}$ and $\mathrm{ARH}$.

\subsubsection{RSSCT with $\mathrm{CRH}$}

Table 2 shows the RSSCT physical design parameters with CRH and the corresponding physical design parameters for large scale column.

\section{$\underline{R S S C T}$ with Pb}

RSSCT with CRH as adsorbents were conducted for 30 hrs at which $95 \%$ breakthrough was reached (Fig. 20). At

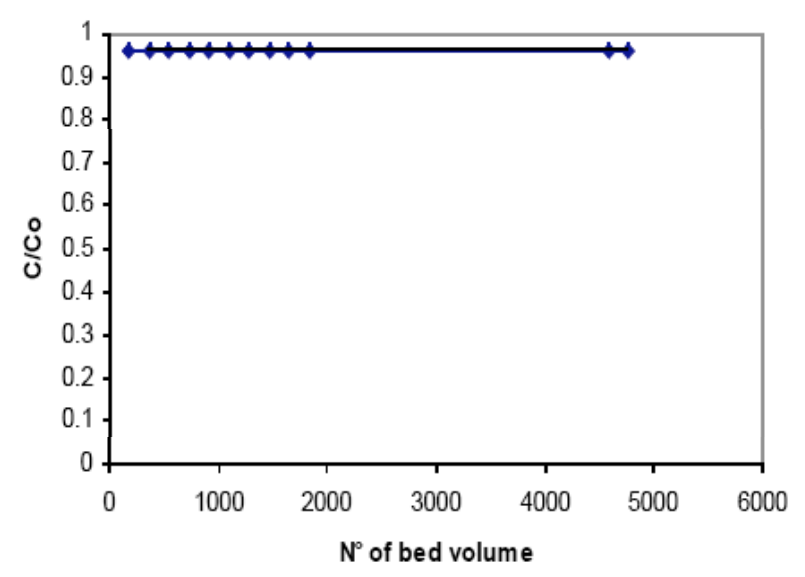

Fig. (21). Breakthrough profile for $\mathrm{Cd}$ with $\mathrm{CRH}$ as adsorbents.

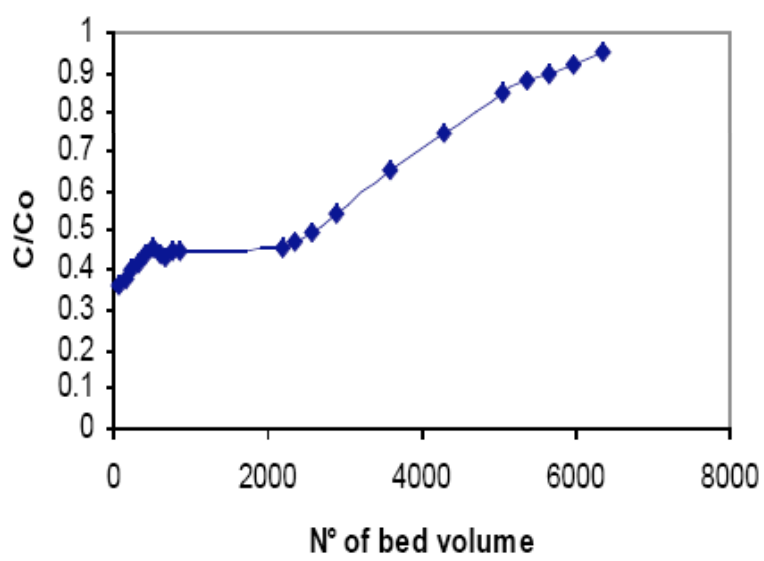

Fig. (22). Breakthrough profile for $\mathrm{Cu}$ with $\mathrm{CRH}$ as adsorbents.

$95 \%$ breakthrough $2.82 \mathrm{mg}$ of $\mathrm{Pb}$ (II) were adsorbed per $\mathrm{g}$ of $\mathrm{CRH}$ was adsorbed and 5443 bed volumes were treated.

\section{$\underline{\text { RSSCT with } C d}$}

RSSCT for cadmium with $\mathrm{CRH}$ as adsorbents were run for $26 \mathrm{hrs}$ at which there was hardly any removal of cadmium with CRH (Fig. 21). However, these results were in agreement with batch adsorption experiment (Fig. 8).

\section{$\underline{\mathrm{RSSCT} \text { with } \mathrm{Cu}}$}

RSSCT for copper with CRH as adsorbents were run for $35 \mathrm{hrs}$ at which $95 \%$ of the $\mathrm{Cu}$ breakthrough was obtained (Fig. 22). At this breakthrough $10.36 \mathrm{mg}$ of $\mathrm{Cu}$ per $\mathrm{g}$ of $\mathrm{CRH}$ was adsorbed and 6350 bed volumes were treated. Shape of the $\mathrm{Cu}$ breakthrough curve was found to be increasing.

\section{$\underline{\text { RSSCT with Zn }}$}

RSSCT for Zn (II) with CRH as adsorbents were conducted for $50 \mathrm{hrs}$ at which $100 \%$ of the breakthrough was obtained. At $100 \%$ of breakthrough $8.026 \mathrm{mg}$ of $\mathrm{Zn}$ (II) per g of CRH was adsorbed and 9568 bed volumes were treated (Fig. 23).

\subsubsection{RSSCT with ARH \\ $\underline{R S S C T}$ with ARH for $P b$}

RSSCT for $\mathrm{Pb}$ with $\mathrm{ARH}$ as adsorbents were run for 35 hrs at which $98 \%$ of the breakthrough was obtained. At $98 \%$ 


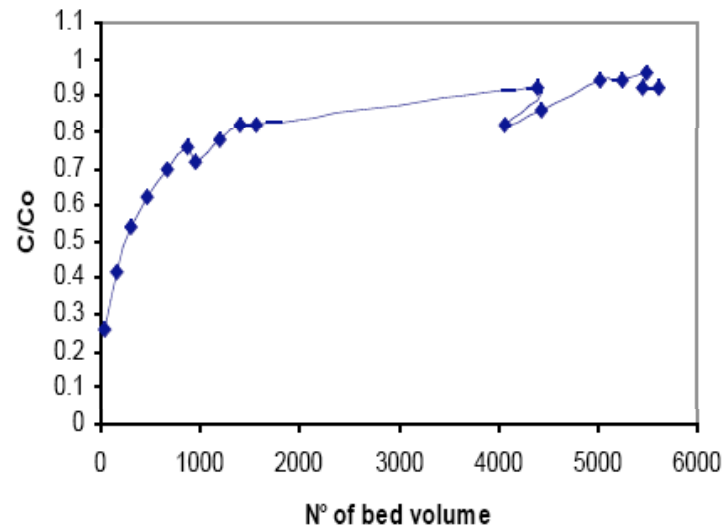

Fig. (23). Breakthrough profile for $\mathrm{Zn}$ with $\mathrm{CRH}$ as adsorbents.

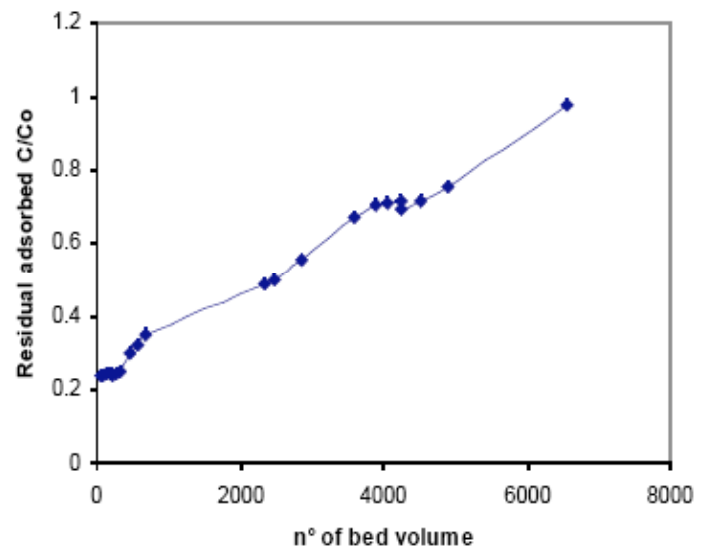

Fig. (24). Breakthrough profile for $\mathrm{Pb}$ with $\mathrm{ARH}$ as adsorbents.

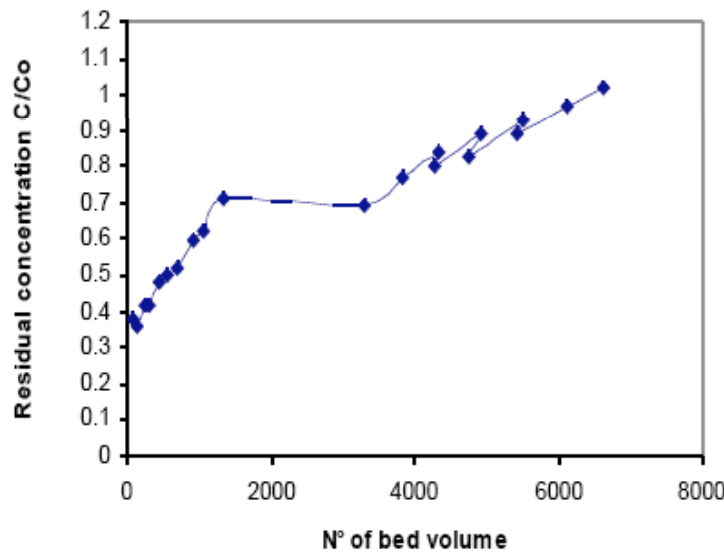

Fig. (25). Breakthrough profile for $\mathrm{Cd}$ with $\mathrm{ARH}$ as adsorbents.

of breakthrough $6.65 \mathrm{mg}$ of $\mathrm{Pb}$ (II) per $\mathrm{g}$ of ARH was adsorbed and 6550 no. of bed volume was treated as shown in Fig. (24). Removal of $\mathrm{Pb}$ (II) with ARH was relatively effective already observed in batch adsorption experiments (Fig. 11).

\section{$\underline{\text { RSSCT with ARH for Cd }}$}

RSSCT for cadmium with ARH as adsorbents were conducted for $34 \mathrm{hrs}$ at which $100 \%$ of the breakthrough was obtained. At $100 \%$ of breakthrough $1.18 \mathrm{mg}$ of cadmium per $\mathrm{g}$ of ARH was adsorbed and 6623 bed volume was treated as depicted in Fig. (25). RSSCT confirmed potential of ARH to

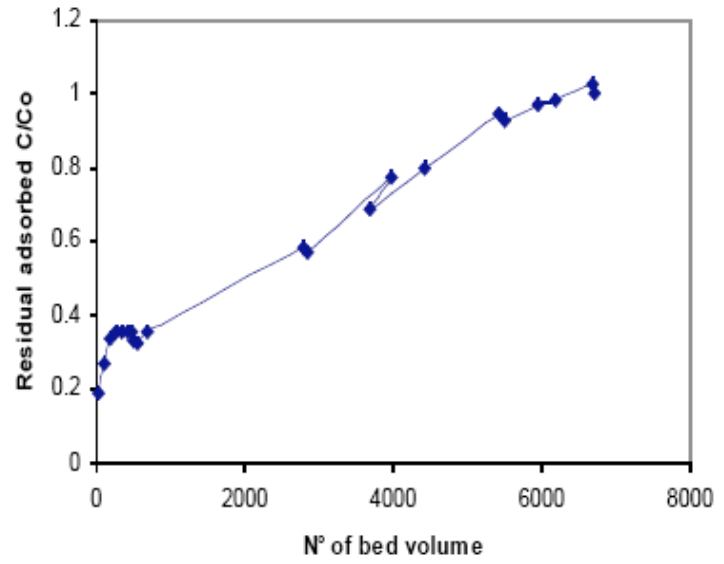

Fig. (26). Breakthrough profile for $\mathrm{Cu}$ with $\mathrm{ARH}$ as adsorbents.

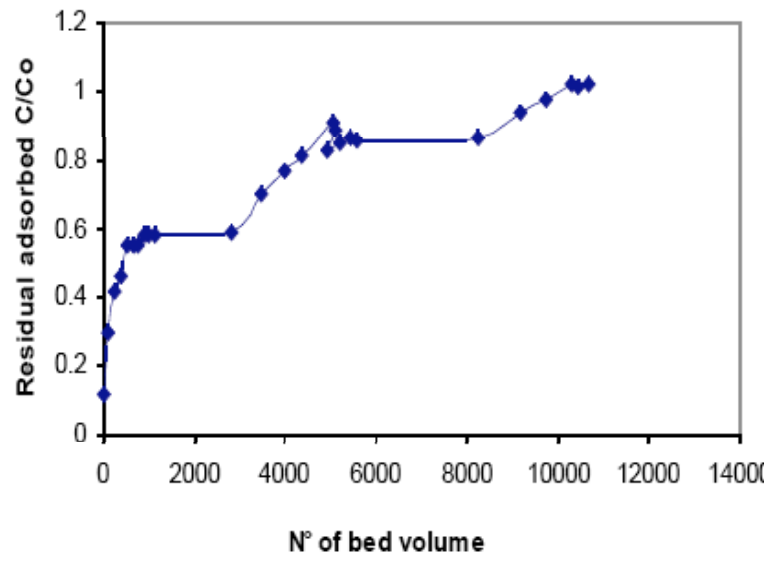

Fig. (27). Breakthrough profile for $\mathrm{Zn}$ with $\mathrm{ARH}$ as adsorbents.

remove $\mathrm{Cd}$ already observed in batch adsorption experiments (Fig. 13).

\section{$\underline{R S S C T}$ with ARH for $\mathrm{Cu}$}

Small scale column test for copper with ARH as adsorbents were run for $35 \mathrm{hrs}$ at which $100 \%$ of the breakthrough was obtained. At $100 \%$ of breakthrough $10.6 \mathrm{mg}$ of copper per $\mathrm{g}$ of ARH was adsorbed and 6718 bed volume was treated as shown in Fig. (26). Cu removal with ARH was effective and $36 \%$ removal as achieved during the first few hrs of operation.

\section{$\underline{R S S C T}$ with ARH for $\mathrm{Zn}$}

RSSCT for Zn (II) with ARH as adsorbents were conducted for $53 \mathrm{hrs}$ at which $100 \%$ of the breakthrough was obtained. At $100 \%$ of breakthrough, $28.24 \mathrm{mg}$ of $\mathrm{Zn}$ per $\mathrm{g}$ of ARH was adsorbed and 10304 bed volumes were treated (Fig, 27). RSSCT confirmed potential of ARH to remove $\mathrm{Zn}$ already observed in batch adsorption experiments (Fig. 17).

\subsection{Comparison of heavy metals adsorption on CRH and ARH based on RSSCT}

Fig. (28) compare the results obtained with RSSCT with $\mathrm{ARH}$ and $\mathrm{CFH}$ as an adsorbents. It was found that $\mathrm{CRH}$ adsorption capacity decrease in the order of $\mathrm{Cu}>\mathrm{Zn}>\mathrm{Pb}>\mathrm{Cd}$ where as adsorption capacity of ARH decreases in the order of $\mathrm{Zn}>\mathrm{Cu}>\mathrm{Pb}>\mathrm{Cd}$. 


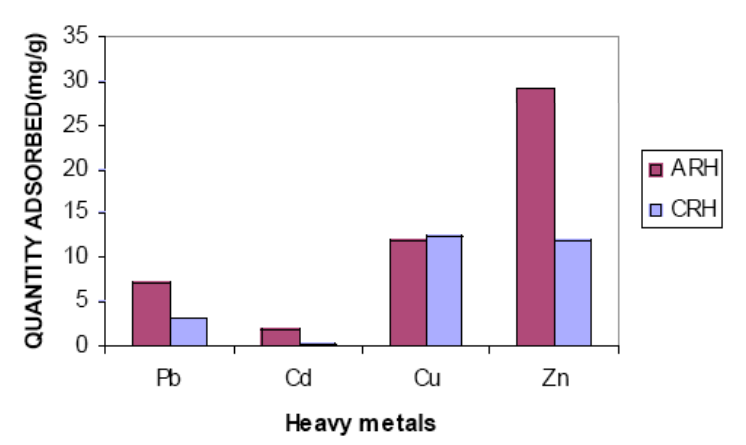

Fig. (28), Comparison of adsorption capacity of ARH and CRH.

\section{CONCLUSIONS}

This study was undertaken to investigate the adsorption of Lead, Cadmium, Copper and Zinc on rice husks based adsorbents Carbonized Rice Husk (CRH) and Activated Rice Husk (ARH). The following conclusions were drawn on the basis of the result obtained from the experiment.

- CRH demonstrated the potential of removing all the studied heavy metals except cadmium at $\mathrm{pH}$ 7. The $\mathrm{CRH}$ adsorption capacity decreases in the order of $\mathrm{Cu}>$ $\mathrm{Pb}>\mathrm{Zn}>\mathrm{Cd}$ in batch adsorption whereas in RSSCT the adsorption capacity decrease as follow $\mathrm{Cu}>\mathrm{Zn}>\mathrm{Pb}>\mathrm{Cd}$. The kinetic removal in batch adsorption experiment decreases in order $\mathrm{Zn}>\mathrm{Pb}>\mathrm{Cu}>\mathrm{Cd}$.

- $\quad$ ARH demonstrated the potential of removing all studied heavy metals under experimental condition applied in this study. Similarly to CRH, in batch experiment the adsorption capacity decreases in the order of $\mathrm{Cu}>\mathrm{Pb}>$ $\mathrm{Zn}>\mathrm{Cd}$. In RSSCT the adsorption capacity decreases in the order $\mathrm{Zn}>\mathrm{Cu}>\mathrm{Pb}>\mathrm{Cd}$. The kinetic removal in batch adsorption experiment for ARH was in agreement with $\mathrm{CRH}$ decreasing order, $\mathrm{Zn}>\mathrm{Pb}>\mathrm{Cu}>\mathrm{Cd}$.

- The kinetic removal in batch experiment showed that the net uptake of $\mathrm{Pb}, \mathrm{Cd}, \mathrm{Cu}, \mathrm{Zn}$ was $54.3 \%, 8.24 \%$, $51.4 \%$ and $56.7 \%$, respectively, whereas using CRH, while it varied as $74.04 \%, 43.4 \%, 70.08 \%$ and $77.2 \%$ for the same dosages of ARH. Therefore, it is concluded that as regards to $\mathrm{CRH}$, ARH demonstrated higher potential to remove relatively all selected heavy metals.

Some additional findings of this study are:

- Further research needs to be carried out on the competitive effects of these dissolved heavy metals with each other on the adsorption.

- The effect of other ions possibly presents in industrial wastewater like $\mathrm{Cr}, \mathrm{Fe}$, As and organic matter on the removal of heavy metals adsorption needs to be carried out.

- As the pH of industrial wastewater varies, the applicability of these adsorbents to remove these heavy metals at different $\mathrm{pH}$ needs further research.

- Further research needs to be carried out on the search of optimum $\mathrm{pH}$ favorable on the adsorption of investigated heavy metals.
- $\quad$ Rice husk's ability to effectively remove dyes, surfactants, phenols present in industrial effluents should also be investigated.

\section{ACKNOWLEDGEMENTS}

The authors are very grateful to Inter-University Council of Eastern Africa through Lake Victoria Research (VicRes) for accepting to pay for the publication of this work. We also thank Nuffic for sponsoring this study through the WREM Project, a collaborative capacity building project between the National University of Rwanda and the UNESCO-IHE Institute for Water Education.

\section{NOMENCLATURE}

$\begin{array}{ll}\% & =\text { Percentage } \\ \mathrm{g} / \mathrm{l} & =\text { Gram per litre } \\ \mathrm{mg} / \mathrm{l} & =\text { Miligram per litre } \\ \mathrm{m} & =\text { Metres } \\ \mathrm{m}^{3} / \mathrm{h} & =\text { Cubic Metres per hour } \\ \mathrm{Pb} & =\text { Lead } \\ \mathrm{Zn} & =\text { Zinc } \\ \mathrm{Cu} & =\text { Copper } \\ \mathrm{Cd} & =\text { Cadmium } \\ \mathrm{R}^{2} & =\text { Correlation Coefficient expressed as a }\end{array}$

\section{ACRONYMS}

$\mathrm{pH}$

$=$ potential of Hydrogen

$\mathrm{CRH}=$ Carbonized Rice Husk

ARH $=$ Activated Rice Husk

RSSCT $=$ Rapid Small Scale Column Tests

SIDA/SAREC $=$ Swedish International Development Cooperation Agency/ Swedish International Development Cooperation Agency

VICRES = Lake Victoria Research Initiative

\section{REFERENCES}

[1] United Nations Development Programme (UNDP), "Millennium Development Goals (2000 - 2015)", New York (USA), 2000

[2] United Nations Industrial Development Organization (UNIDO), “Annual Report 2008”, Industrial Development Board, Vienna (Austria), 2008

[3] Ministry of Agriculture Animal Resources, Rwanda (MINAGRI), "Technical Report of Rwanda Government", Kigali, Rwanda 2007.

[4] Kigali Conceptual Master Plan Team (KCMPT), "Kigali Conceptual Master Plan Draft, Existing Conditions Analysis', Ministry of Infrastructure. Kigali, Rwanda, 2007

[5] B.H. Rao, A. Dalinaidu and D.N. Singh, "Accelerated diffusion test on the intact rock mass", Journal of Testing and Evaluation, ASTM, vol. 35(2), pp. 111- 117, 2007

[6] A.M.M. Khaled, "A Comparative study for distribution of some heavy metals in aquatic organisms fished from Alexandria region", $\mathrm{PhD}$ Thesis, Chemistry Department, Faculty of Science. Alexandria University, Egypt, 1998. 
[7] A.M. Nurul, K. Satoshi, K. Taichi, B. Aleya, and K. Hideyuki, "Removal of arsenic in aqueous solutions by adsorption onto waste rice husk", Industrial Engineering and Chemical Research, vol. 45, pp. 8105-8110, 2006.

[8] C.C. Chen, and Y.C. Chung, "Arsenic removal using a biopolymer chitosan sorbent”, Journal Environmental Science and Health, vol. 41, pp. 645-658, 2006.

[9] D.F. Aloko, and E. A. Afolabi, "Model Development of the adsorption of cations on Manganese dioxide $\left(\mathrm{MnO}_{2}\right)$ used in a Leclanche dry cell", Leonardo Journal of Sciences, vol. 8, pp. 13-20, 2006.

[10] D.F. Aloko, and E. A. Afolabi, "Titanium dioxide as a cathode material in a dry cell", Leonardo Electronics Journal of Practices and Technologies, vol. 11, pp. 97-108, 2007.

[11] R. Ahmed, T. Yamin., M. S. Ansari, and S. M. Hassany, "Sorption behavior of Lead (II) ions from aqeous solution onto Haro River sand", The Nucleus, vol. 24(6), pp. 475-486, 2009.

[12] M.F.A.Umuhoza, I. Nhapi, U.G. Wali, and N. Banadda, "Assessment of Wastewater Management Practices in Kigali City, Rwanda", The Open Environment and Biological Monitoring Journal, vol. 3, pp. 21-28, 2010
[13] Rwanda Bureau of Standards (RBS), "Technical Report of the Rwanda Bureau of Standards", Kigali, Rwanda, 2008.

[14] S. Ayub, S.I. Ali, N.A. Khan, and R.A.K. Rao, "Treatment of wastewater by Agricultural waste", Environmental Protection Control Journal, vol. 2(1), pp. 5-8, 1998.

[15] K. Srinivasan, N. Balasubramaniam, and T.V. Ramakrishna, "Studies on chromium removal by rice husk carbon", Indian Journal Environmental Health, vol. 30(4), pp. $376-387,1998$.

[16] K. Selvi, S. Pattabhi, and K. Kadirvelu, "Removal of Cr (VI) from aqueous solution by adsorption onto activated carbon", Bioresource Technology, vol. 80, pp. 87-89, 2001.

[17] K. Kadirvelu, K. Thamaraiselvi, and C. Namasivayam, "Removal of heavy metals from industrial wastewaters by adsorption onto activated carbon prepared from an agricultural solid waste", Bioresource Technology, vol. 76(1), pp. 63-65, 2001.

[18] N.A. Khan, S. Ibrahim, and P. Subramaniam, "Elimination of heavy metals from wastewater using Agricultural wastes as adsorbents”, Malaysian Journal Science, vol. 23, pp. 43-51, 2004.

[19] W. Nakbanpote, P. Thiravetyan, and C. Kalambaheti, "Preconcentration of gold by rice husk ash", Minerals Engineering, vol. 13, pp. 391-400, 2000

(C) Murenzi et al.; Licensee Bentham Open.

This is an open access article licensed under the terms of the Creative Commons Attribution Non-Commercial License (http://creativecommons.org/licenses/by-nc/3.0/g) which permits unrestricted, non-commercial use, distribution and reproduction in any medium, provided the work is properly cited. 